\title{
Relationship between pituitary GnRH-binding sites and pituitary release of gonadotrophins in post-partum beef cows
}

\author{
K. Leung*†, V. Padmanabhan*, L. J. Spicer*, H. A. Tucker*, R. E. Short $\ddagger$ \\ and E. M. Convey*§
}

* Animal Reproduction Laboratory, Department of Animal Science, Michigan State University, East Lansing, Michigan 48824 and $\ddagger$ Livestock and Range Research Station, United States Department of Agriculture, Miles City, Montana 59301, U.S.A.

\begin{abstract}
Summary. Thirty primiparous suckling beef cows were slaughtered on Day 7, 14, 28, 42 or 56 after parturition. Some had resumed oestrous cyclicity by the time they were slaughtered on Days 42 and 56. Amongst acyclic cows between Days 7 and 42, pituitary LH concentrations and basal and GnRH-induced release of LH from pituitary explants doubled. Pituitary FSH concentration and basal release in FSH increased only by $15-20 \%$, while GnRH-induced release of FSH in vitro was unchanged. During postpartum anoestrus, overall mean concentrations of serum FSH did not change, whereas overall mean concentrations and pulse amplitudes of serum LH increased. Numbers and affinity constants of GnRH-binding sites in pituitary glands remained constant during the post-partum period studied. We conclude that, under these experimental conditions, numbers and affinity constants of GnRH-binding sites in the pituitary gland of post-partum beef cows do not limit the ability of the anterior pituitary gland to release gonadotrophins.
\end{abstract}

\section{Introduction}

After parturition, beef cattle go through a period of anoestrus before resumption of oestrous cyclicity. Insufficient secretion of LH from the anterior pituitary gland is one reason for anoestrus. This view is based upon the following observations. After calving, pituitary LH content (Labhsetwar, Collins, Tyler \& Casida, 1964; Saiduddin, Riesen, Tyler \& Casida, 1968; Cermak, Braden, Manns, Niswender \& Nett, 1983), GnRH-induced release of LH (Kesler, Garverick, Youngquist, Elmore \& Bierschwal, 1977; Webb, Lamming, Haynes, Hafs \& Manns, 1977; Fernandes, Thatcher, Wilcox \& Call, 1978) and mean concentrations of LH in serum (Peters, Lamming \& Fisher, 1981; Williams et al., 1982) were lower than those observed just before the first post-partum oestrus. Similar changes in these indices of LH secretion occur in sheep (Jenkin, Heap \& Symons, 1977). Gradual restoration of GnRH-induced release of LH in women during the puerperium has also been reported (Jeppsson, Rannevik \& Kullander, 1974; LeMaire, Shapiro, Riggall \& Yang, 1974).

Binding of GnRH to specific sites in the plasma membrane of gonadotrophs is the first step in stimulation of LH secretion. Any changes in either the number or affinity constant of the GnRH-binding sites may alter the sensitivity of gonadotrophs to GnRH. Therefore, reduced LH

\footnotetext{
$\nmid$ Present address: Developmental and Reproductive Biology, University of Michigan, $300 \mathrm{~N}$. Ingalls Bldg, 11th Floor, Ann Arbor, Michigan 48109, U.S.A.

§Present Address: Merck, Sharp \& Dohme Research Laboratories, Rahway, New Jersey 07605, U.S.A.
} 
secretion during the post-partum period in cattle may be due to reduced numbers and/or affinity of GnRH-binding sites. Clayton, Solano, Garcia-Vela, Dufau \& Catt (1980) and Clayton \& Catt (1981) have reported that lactating rats have about half the number of pituitary GnRH-binding sites that are found in rats in metoestrus; affinity constants did not change. In the experiment described herein, we evaluated whether the ability of the pituitary gland of post-partum beef cows to release gonadotrophins in response to $\mathrm{GnRH}$ was related to the number and affinity constant of GnRH-binding sites in the same pituitary gland.

\section{Materials and Methods}

\section{Animals}

Primiparous crossbred (primarily Hereford $\times$ Angus) cows were obtained from the Upjohn Company (Kalamazoo, MI, U.S.A.). They were about 2 years old when artificially inseminated between 22 September and 16 October after synchronization of oestrus with prostaglandin F-2 $\alpha$ (Upjohn, Kalamazoo, MI, U.S.A.). These cows averaged $479 \pm 13 \mathrm{~kg}$ body weight and had a score of 7 out of a possible 10 for body condition (fat) just before parturition. Cattle were fed to meet requirements established by the National Research Council (1976). Feeds consisted of corn silage supplemented with vitamins and minerals. All cows were 'halter-broken' and accustomed to handling before parturition. Parturition occurred between 1 and 24 July. Each cow suckled a single calf until slaughter.

The cows were assigned randomly to be slaughtered on Days 7, 14, 28, 42 or 56 after parturition. Housing was in groups of 56 cows per pen.

\section{Blood samples}

A pen was modified for collection of blood samples from an adjacent room via a remote cannula fitted into a jugular vein of each cow. Cows and calves were acclimatized to this pen 4 days before collection of blood. On the day before slaughter, cows were bled at 10 -min intervals between 08:00 and 14:00 h. During the sampling period, cows were loosely restrained with halters and calves had free access to dams. Blood was stored for $2 \mathrm{~h}$ at room temperature, then at $4^{\circ} \mathrm{C}$ for an additional $24 \mathrm{~h}$ before centrifugation to obtain serum. Serum was stored at $-20^{\circ} \mathrm{C}$ until concentrations of LH and FSH were measured.

Beginning on Day 21 after parturition, blood was also collected by venepuncture every 3 days until time of slaughter. These samples were assayed for progesterone. Serum concentrations of progesterone greater than $1 \mathrm{ng} / \mathrm{ml}$ and the presence of newly formed corpora lutea at slaughter were used to estimate when these cows resumed oestrous cycles.

\section{Anterior pituitary glands}

Pituitary glands were collected and packed in ice within $15 \mathrm{~min}$ after cows were killed. Anterior pituitary glands were isolated and bisected. Pituitary halves from each animal were weighed and then randomly assigned either to be stored in liquid nitrogen until quantification of GnRH-binding sites or to be incubated in vitro to determine the ability of the gland to release gonadotrophins.

Quantification of GnRH-binding sites in anterior pituitary glands. A hemi-pituitary gland from each cow was homogenized in $15 \mathrm{ml}$ Tris- $\mathrm{HCl}$ buffer ( $\mathrm{pH} \mathrm{7.7,10} \mathrm{mM-Tris} \mathrm{with} 1 \mathrm{~mm}$-dithiothreitol) using an Omni-mixer ( $50 \mathrm{ml}$ container; Sorvall, Norwalk, CT, U.S.A.) at maximum speed for $2 \mathrm{~min}$. The resulting slurry was homogenized further with a hand-driven tissue grinder (glass to glass, Pyrex No. $7726,0 \cdot 15 \mathrm{~mm}$ clearance, 10 strokes): $200 \mu \mathrm{l}$ of this homogenate were stored at $-70^{\circ} \mathrm{C}$ until assayed for $\mathrm{LH}$ and $\mathrm{FSH}$. A crude membrane fraction was prepared from the remaining homogenate as described previously (Leung, Padmanabhan, Convey, Short \& Staigmiller, 
1984). Binding assays for GnRH were carried out for individual hemi-pituitaries, and Scatchard analyses were subsequently performed. Numbers of binding sites are expressed as $\mathrm{fmol} / \mathrm{mg} \mathrm{mem-}$ brane protein. Protein was assayed as described by Lowry, Rosebrough, Farr \& Randall (1951) using bovine serum albumin as standard.

GnRH analogue, D-Ala ${ }^{6}$-des-Gly ${ }^{10}$-GnRH ethylamide (GnRH-A; Peninsula Laboratories, San Carlos, CA, U.S.A.) was iodinated by a lactoperoxidase-glucose oxidase method (Clayton et al., 1979). Specific activity was calculated as described previously (Leung et al., 1984) and ranged from 1152 to $2017 \mu \mathrm{Ci} / \mu \mathrm{g}$. The maximal percentage of specific binding of ${ }^{125} \mathrm{I}$-labelled $\mathrm{GnRH}-\mathrm{A}$ to an excess of membrane protein varied with iodinations and ranged from 28 to $43 \%$. Total radioactivity added to each assay tube was corrected for variation in maximal specific binding before Scatchard analysis. The assay was carried out as previously reported (Leung et al., 1984) and radioactivity was measured in a gamma spectrometer with a counting efficiency of $85 \%$.

Fresh and frozen anterior pituitary glands. Before assay we planned to hold all pituitary glands in liquid nitrogen until the end of the experiment when all the heifers were killed. But we were concerned that numbers and/or affinity of GnRH-binding sites might change with freezing. Therefore, we performed a preliminary experiment to test this question. Anterior pituitary glands were obtained from cows killed at a local abattoir, bisected, and the halves were randomly assigned to be used fresh or after freezing in liquid nitrogen for $2 \mathrm{~h}$ followed by thawing over a 15-min period. Binding assays were run on each pituitary half. Neither the affinity constants $(0.96 \pm 0.12$ and $\left.0.98 \pm 0.12 \times 10^{10} \mathrm{M}\right)$ nor numbers $(94.4 \pm 22.8$ and $99.1 \pm 22.5 \mathrm{fmol} / \mathrm{mg}$ protein) of GnRH-binding sites in the crude membrane preparation from frozen pituitary halves were different $(P<0.25)$ from those prepared from fresh halves. Pituitary halves were therefore stored in liquid nitrogen until time of assay (34-40 weeks). GnRH-binding sites in all pituitary glands were quantitated within a single assay. Intra-assay coefficient of variation was $5 \cdot 9 \%$.

Ability of the anterior pituitary gland to release gonadotrophins. To determine changes in ability of anterior pituitary glands to release $\mathrm{LH}$ and $\mathrm{FSH}$, one half of the fresh anterior pituitary gland from each animal was sliced and diced into $1-2 \mathrm{~mm}^{3}$ explants. These pituitary explants $(20-25 \mu \mathrm{g})$ were incubated in $4 \mathrm{ml}$ culture medium contained in a $25 \mathrm{ml}$ Erlenmeyer flask under an atmosphere of $95 \% \mathrm{O}_{2}$ and $5 \% \mathrm{CO}_{2}$ at $37^{\circ} \mathrm{C}$. Culture medium consisted of Hank's minimum essential medium and Medium 199 in $1: 1(\mathrm{v} / \mathrm{v})$ ratio supplemented with $5 \mathrm{~mm}-\mathrm{L}-$ glutamine (Gibco, Grand Island, NY, U.S.A.). Explants were first washed with $4 \mathrm{ml}$ culture medium at 15 -min intervals for $1 \mathrm{~h}$ and then incubated in the absence of any treatment for $2 \mathrm{~h}$ to establish basal release of gonadotrophins into medium. At the end of $2 \mathrm{~h}$, the medium was changed and explants were challenged with $4 \mathrm{ng}$ GnRH (Beckman, Palo Alto, CA, U.S.A.) per flask for an additional $2 \mathrm{~h}$. Again, medium was collected after the challenge. All samples of medium were assayed for LH and FSH.

\section{Radioimmunoassays}

Concentrations of LH in all serum and medium samples were determined in 4 assays using a double-antibody procedure previously validated in this laboratory (Convey, Beal, Seguin, Tannen \& Lin, 1976). Standard LH was NIH-LH-B8. Inter- and intra-assay coefficients of variation from 4 assays were $12 \cdot 1$ and $11 \cdot 6 \%$, respectively. Sensitivity of the LH assay was $0 \cdot 125 \mathrm{ng} /$ tube.

Serum and medium FSH were quantified by radioimmunoassay using USDA-FSH-B1 as standard. Rabbit anti-bovine FSH serum (B-5; $1: 75000$ dilution) and highly purified bovine FSH were supplied by Dr K. W. Cheng, University of Manitoba, Winnipeg, Manitoba, Canada. The assay was performed as previously described (Carruthers, Convey, Kesner, Hafs \& Cheng, 1980).

Hormone specificity of binding of ${ }^{125} \mathrm{I}$-labelled bovine FSH to the FSH antiserum was determined in the presence of various amounts of bovine TSH (Dr J. G. Pierce, University of California at Los Angeles, U.S.A.), bovine LH (R-107, Dr L. E. Reichert, Albany Medical College, NY, U.S.A.), bovine FSH, NIH-GH-B18, NIH-prolactin-B5 and USDA-FSH-B1 (Fig. 1). Cross-reaction was calculated as follows: 


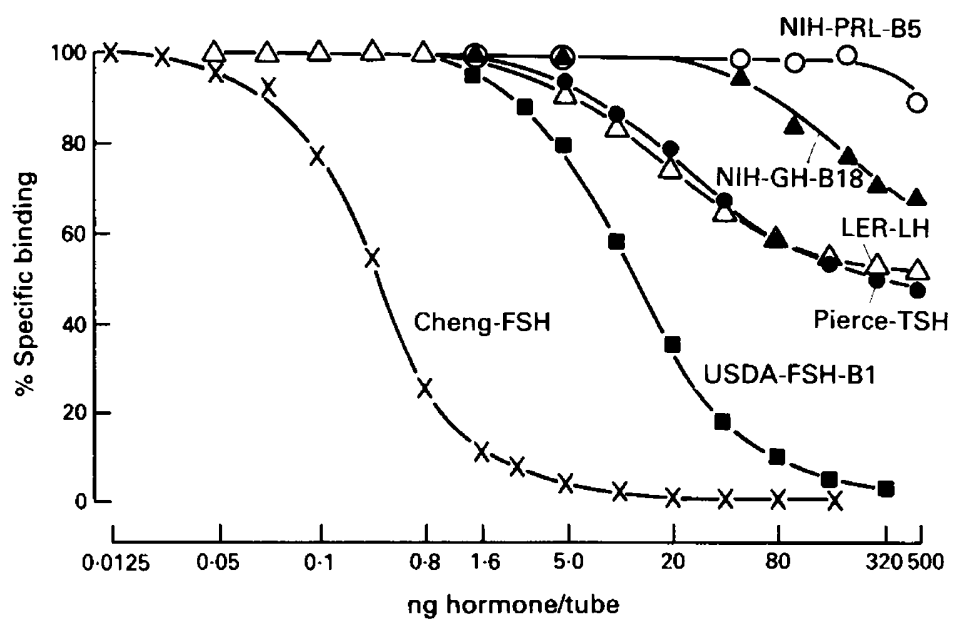

Fig. 1. Cross-reaction of anti-bovine FSH serum with various pituitary hormone preparations. Description of hormone preparations is in 'Materials and Methods'.

$\begin{gathered}\text { amount of USDA-FSH-B1 required to reduce } \\ \text { binding of }{ }^{125} \mathrm{I}-\text {-labelled FSH to } 50 \%\end{gathered}$
$\begin{gathered}\text { amount of other pituitary hormone required } \\ \text { to reduce binding of }{ }^{125} \mathrm{I} \text {-labelled FSH to } 50 \%\end{gathered}$

Cross-reaction of the antiserum with bovine prolactin and GH was $<0.5 \%$, while crossreactions with bovine TSH and LH were about $2 \cdot 6 \%$. Highly purified bovine FSH was 29 times more potent than USDA-FSH-BI in displacing bound ${ }^{125}$ I-labelled FSH from the antiserum.

Displacement of ${ }^{125} \mathrm{I}$-labelled FSH by increasing volumes of cow serum (Day 3 of oestrous cycle), ovariectomized heifer serum and media from cultures of pituitary explants (two pools) was parallel to the standard curves (Fig. 2). Known quantities of FSH (NIH-FSH-B1) were added to cow serum, ovariectomized heifer serum and culture medium: recoveries were 125,132 and $93 \%$, respectively.

Sensitivity of the FSH assay was $2 \cdot 5 \mathrm{ng} /$ tube. Inter- and intra-assay coefficients of variation from 3 assays were $10 \cdot 8$ and $8 \cdot 1 \%$ respectively.

\section{Statistical analysis}

Acyclic vs cyclic cows. At slaughter, 10 of the 30 cows had corpora lutea and concentrations of serum progesterone $>1 \mathrm{ng} / \mathrm{ml}$, indicating resumption of oestrous cyclicity. Therefore, data from the cows were arranged into the following six groups: those that were acyclic on post-partum Days $7(\mathrm{~N}=6), 14(6), 28(5)$ or $42(3)$ and those that were cyclic on post-partum Days $42(5)$ or 56 (5). Since beef cows resumed oestrous cyclicity on different post-partum days and were slaughtered on fixed post-partum days, means of variables obtained on Days 42 and 56 from cyclic cows represented different days of the oestrous cycle.

Evaluation of serum hormones. The following criteria were used:

pulse $=$ one or more consecutive values that exceeded a preceding value by 3 standard deviations (s.d.) established from control serum values run in the same assay $(3 \mathrm{s.d} .=0.3 \mathrm{ng} / \mathrm{ml}$ for LH and $7.5 \mathrm{ng} / \mathrm{ml}$ for FSH);

nadir $=$ lowest point(s) between two defined and adjacent pulses; 
baseline for animals with pulsatile release = mean of all samples that were equal to nadir or within the range of nadir \pm assay sensitivity;

baseline for animals with no pulsatile release = mean of all serum samples;

amplitude $=$ the difference between maximal value reached during a pulse and the nadir preceding the pulse.

\section{Analysis of data}

All data reported were tested for heterogeneity of variance amongst groups using Bartlett's test (Gill, 1978). Heterogeneity was found in variances of baseline concentrations and overall mean concentrations of serum LH. Therefore, data of these two variables were subjected to natural logarithmic transformation before statistical analysis. Data are presented untransformed. All data were analysed by one-way analysis of variance. Specific comparisons of means were conducted using Bonferroni's $t$ test (Gill, 1978).

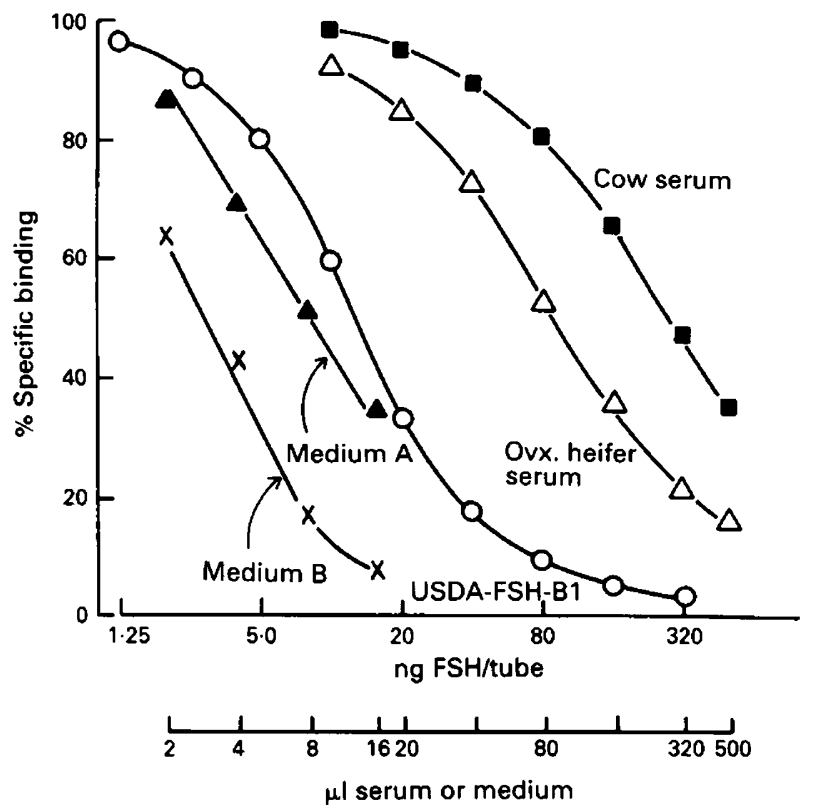

Fig. 2. FSH standard curve and inhibition curves by bovine sera and media from bovine pituitary explant cultures. Description of materials is in 'Materials and Methods'.

\section{Results}

\section{Cows and calves}

Thirteen bull calves and 17 heifer calves were born. Sex and birth weight of the calves and gestation lengths did not differ amongst groups $(P>0.25)$. Calves had a mean ( \pm s.e.m.) birth weight of $26.4 \pm 0.6 \mathrm{~kg}$, and gestation lengths averaged $277.8 \pm 0.6$ days. No major calving difficulty was encountered. 


\section{In-vitro relese of gonadotrophins}

Basal release of $\mathrm{LH}$ and FSH. Among acyclic cows between Days 7 and 42 after parturition, basal release of $\mathrm{LH}$ into the medium increased linearly $(P<0.005)$ from 9.1 to $20.2 \mathrm{ng} / \mathrm{ml}$ medium/mg pituitary gland, and basal release of FSH increased linearly $(P<0.025)$ from 136 to $164 \mathrm{ng} / \mathrm{ml}$ medium/mg pituitary gland (Fig. 3). By Days 28 to 42 after parturition, basal releases of LH and FSH from acyclic cows were comparable $(P>0 \cdot 20)$ to those of cyclic cows on Days 42 and 56 after parturition.

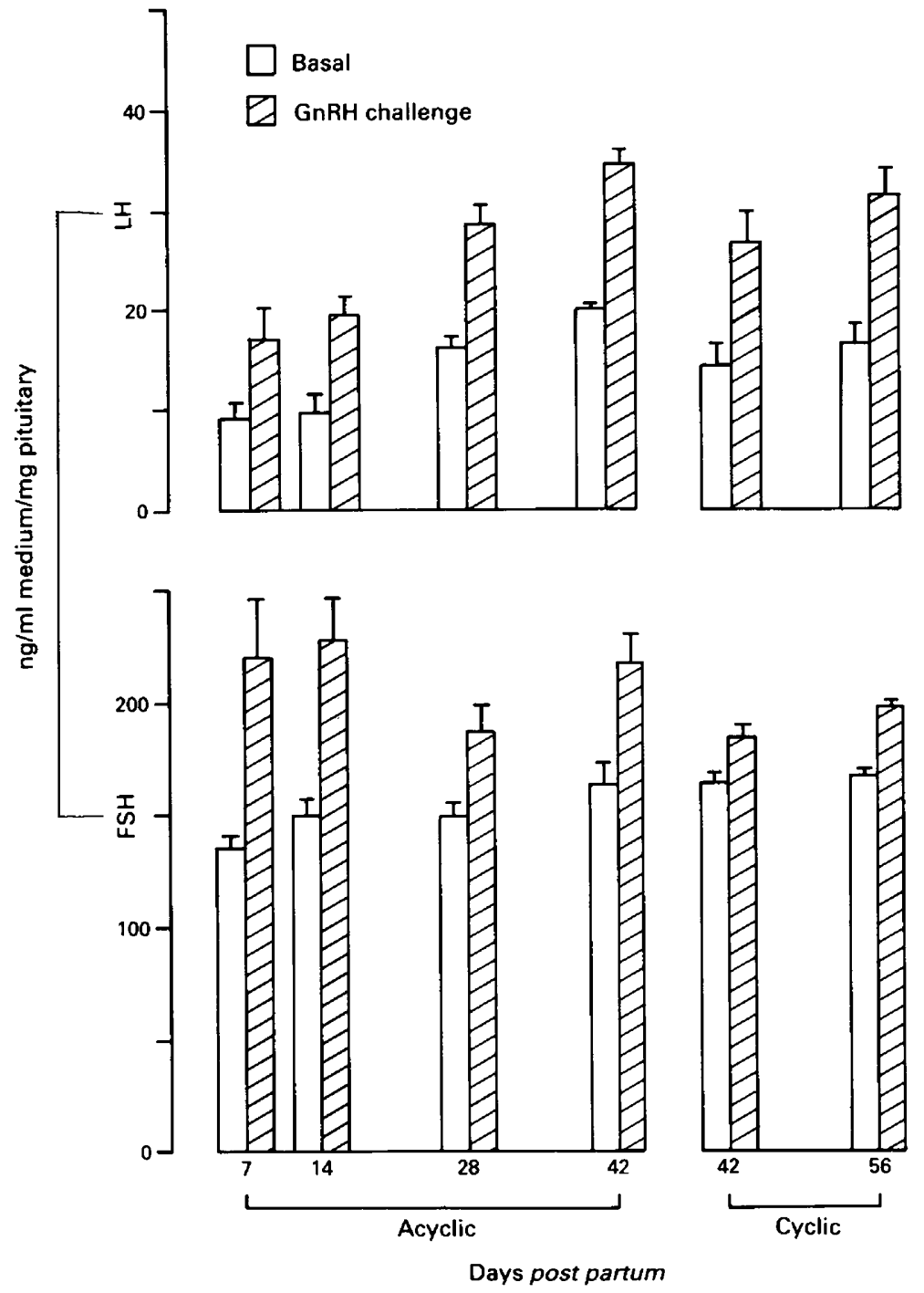

Fig. 3. Concentration of basal and GnRH-induced release of LH and FSH from pituitary explants of post-partum beef cows. Values are means \pm s.e.m. 


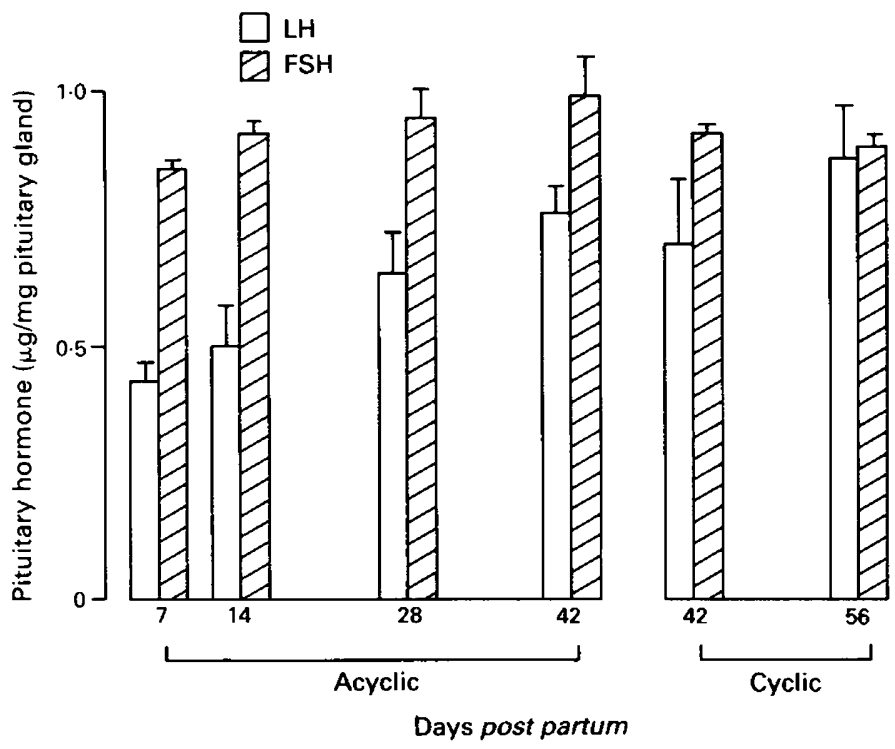

Fig. 4. Concentrations of $\mathrm{LH}$ and FSH in anterior pituitary glands of post-partum beef cows. Values are means \pm s.e.m.

$G n R H$-induced release of $L H$ and $F S H$. The profile of GnRH-induced release of $\mathrm{LH}$ from pituitary explants paralleled basal release of $\mathbf{L H}$ (Fig. 3). There was a linear increase $(P<0.05)$ in $\mathrm{GnRH}$-induced release of $\mathrm{LH}$ into medium from $17 \cdot 1$ to $34.8 \mathrm{ng} / \mathrm{ml}$ medium $/ \mathrm{mg}$ pituitary gland between Days 7 and 42 after parturition. GnRH-induced release of LH in acyclic cows on Days 28 to 42 after parturition was similar $(P>0 \cdot 20)$ to that of cyclic cows on Days 42 and 56 after parturition. GnRH-induced release of FSH into medium, however, did not vary $(P>0 \cdot 20)$ between Days 7 and 56 after parturition within acyclic cows or between acyclic and cyclic cows (Fig. 3).

Concentrations of LH or FSH in medium in response to GnRH did not change $(P>0 \cdot 20)$ between Days 7 and 42 after parturition when expressed as the difference between basal and $\mathrm{GnRH}$-induced release of LH or FSH from pituitary explants.

\section{Pituitary concentrations of $\mathrm{LH}$ and FSH}

Within acyclic cows, pituitary $\mathrm{LH}$ concentrations $(\mu \mathrm{g} / \mathrm{mg}$ pituitary tissue) increased from 0.43 to 0.76 and pituitary FSH concentrations from 0.85 to 0.99 between Days 7 and 42 after parturition (Fig. 4). Both increases were linear $(P<0 \cdot 05)$. By Days 28 to 42 after parturition, pituitary concentrations of $\mathrm{LH}$ of acyclic cows were similar $(P>0 \cdot 20)$ to those of cyclic cows on Days 42 and 56 after parturition. Pituitary gland concentrations of FSH did not vary $(P>0 \cdot 20)$ between cyclic and acyclic cows.

There were positive correlations $(P<0 \cdot 001)$ between LH concentrations in pituitary glands and basal $(r=0.76)$ and $\mathrm{GnRH}$-induced $(r=0.75)$ releases of LH from pituitary explants in culture. A positive correlation was also detected $(r=0.53 ; P<0.005)$ between FSH concentration in the pituitary gland and basal release of FSH from the explants.

\section{GnRH-binding sites}

Affinity constants and numbers of GnRH-binding sites in the pituitary glands did not change with time after parturition or between acyclic and cyclic cows $(P>0 \cdot 25$, Table 1$)$. 
Table 1. Mean ( \pm s.e.m.) affinity constants and numbers of GnRH-binding sites in anterior pituitary glands of post-partum beef cows

\begin{tabular}{lcccc}
\hline Status & $\begin{array}{c}\text { Days } \\
\text { post partum }\end{array}$ & $\begin{array}{c}\text { No. of } \\
\text { cows }\end{array}$ & $\begin{array}{c}\text { Affinity constants } \\
\left(\times 10^{10} \mathrm{M}^{-1}\right)\end{array}$ & $\begin{array}{c}\text { No. of binding sites } \\
(\mathrm{fmol} / \mathrm{mg} \text { protein })\end{array}$ \\
\hline Acyclic & 7 & 6 & $0.79 \pm 0.09$ & $98.3 \pm 13.8$ \\
& 14 & 6 & $0.73 \pm 0.05$ & $119.9 \pm 15 \cdot 7$ \\
& 28 & 5 & $0.67 \pm 0.06$ & $129.0 \pm 18.6$ \\
Cyclic & 42 & 3 & $0.81 \pm 0.04$ & $81.8 \pm 12.3$ \\
& 42 & 5 & $0.71 \pm 0.03$ & $136.6 \pm 25.8$ \\
& 56 & 5 & $0.81 \pm 0.07$ & $94.8 \pm 11.4$ \\
\hline
\end{tabular}

\section{Indices of serum gonadotrophins}

$L H$. Indices of serum LH are presented in Fig. 5. Frequency of pulses and mean baseline concentrations of $\mathrm{LH}$ did not change with time after parturition, or when oestrous cyclicity resumed $(P>0 \cdot 20)$. Although overall mean concentrations of LH tended to be lower on Day 7 than on Days 14 to 42 , these differences only approached significance $(P>0 \cdot 10)$. The mean amplitude of LH pulses observed on Days 14, 28 and 42 after parturition was greater $(P<0.05)$ than that on Day 7 $(2.4 \pm 0.2 v s 1.3 \pm 0.4 \mathrm{ng} / \mathrm{ml}$, respectively). The average amplitude of pulsatile $\mathrm{LH}$ release between
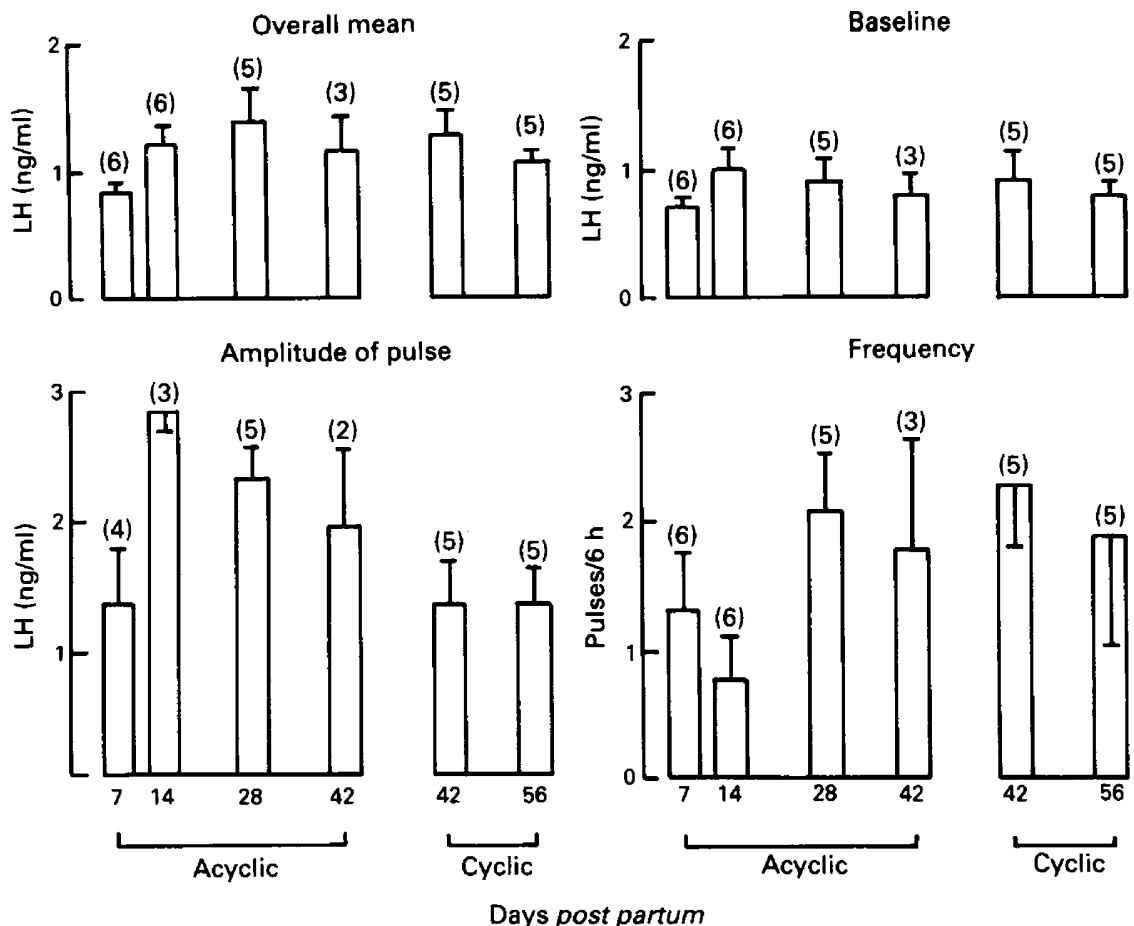

\section{Days post partum}

Fig. 5. Indices of serum $\mathrm{LH}$ in post-partum beef cows. Values are means \pm s.e.m. for the no. of cows in parentheses. 
Days 7 and 42 after parturition amongst acyclic cows was higher $(P<0.05)$ than that of cyclic cows $(2 \cdot 1 \pm 0 \cdot 2$ vs $1 \cdot 3 \pm 0 \cdot 3 \mathrm{ng} / \mathrm{ml}$ respectively).

$F S H$. Frequencies and amplitudes of the FSH pulses, mean baseline concentrations and overall mean concentrations of serum FSH did not change $(P>0 \cdot 20)$ among all days studied.

\section{Discussion}

Under the in-vitro conditions in the present study, the test of pituitary response to a presumed maximal dose of $\mathrm{GnRH}$ revealed that concentrations of medium $\mathrm{LH}$ after $\mathrm{GnRH}$ were about 1.9 times that before GnRH for all times studied. Therefore, in this study, an increase in release of LH with time from parturition was probably due to increased ability of the pituitary gland to release $\mathrm{LH}$. This increase in the ability of the pituitary gland to release $\mathrm{LH}$ was not accompanied by alteration in either the affinity constant or number of GnRH-binding sites in the pituitary gland. There is therefore no direct relationship between numbers and affinity constants of GnRH-binding sites in the pituitary gland of post-partum beef cows and the ability of the gland to release gonadotrophins. This observation is similar to that deduced by Leung et al. (1984) for cattle and by Ferland et al. (1981) for rats during pro-oestrus of their respective cycles. However, the number of GnRH-binding sites was greater in the present study than we have previously reported (Leung $e t$ al., 1984) and we consider that variation amongst animals may account for the difference.

Evidence suggests that the number of GnRH-binding sites is in excess, i.e. occupancy of only a fraction of GnRH-binding sites is required for maximal LH release. Naor, Clayton \& Catt (1980) showed that occupancy of $20 \%$ of GnRH-binding sites elicited about $80 \%$ of the maximal $\mathrm{LH}$ release from cultured rat pituitary cells. Therefore, even with the variation in the number of GnRH-binding sites observed in the present study, there may be sufficient numbers of binding sites to mediate maximal release of $\mathrm{LH}$.

In other studies (Savoy-Moore, Schwartz, Duncan \& Marshall, 1980; Clayton et al., 1980), GnRH-binding sites were measured in a crude fraction of membranes of the anterior pituitary gland. This crude membrane preparation consists of plasma membrane as well as other intracellular membranes. Consequently, other GnRH-binding sites not associated with plasma membrane may also be measured in their assays; for example, GnRH-binding to secretory granules (Sternberger \& Petrali, 1975; Morel, Barry \& Dubois, 1980) and nuclei (Millar, Rosen, Badminton, Pasqualini \& Kerdelhue, 1983) has been reported. However, this concern does not apply to the present study. Most of the secretory granules and nuclei were removed from the final preparation of membrane by differential centrifugation. Even with this modification, however, no change in either the number or affinity constant of GnRH-binding sites in these preparations was detected. Therefore, our data provide convincing evidence for the discordant relationship between the ability of the pituitary gland to release gonadotrophins and number and affinity constant of GnRH-binding sites in the same pituitary gland.

Moss, Adams, Niswender \& Nett (1980) reported that a constant percentage of total LH was released from dispersed pituitary cells of post-partum ewes after stimulation with a maximal dose of $\mathrm{GnRH}$. These authors suggested that only a certain percentage of LH in the anterior pituitary gland was readily releasable. If this hypothesis is correct, as the concentrations of pituitary LH increase during post-partum anoestrus, we would expect increased amounts of LH to be available for release. Indeed, this phenomenon may explain the positive correlations in the present study between concentrations of LH in the pituitary gland and either basal or GnRH-induced release of LH from pituitary explants. Furthermore, the bulk of the evidence in the present study and that of Peters et al. (1981) and Williams et al. (1982) suggest that there is an increase in overall mean concentrations of $\mathrm{LH}$ in serum shortly after parturition. In addition, we observed an increase in amplitude of LH pulses. These increases in storage and release of LH may be prerequisite for the re-establishment of the first post-partum preovulatory surges of gonadotrophins. 
The $20 \%$ increase in basal release of FSH from pituitary explants during post-partum anoestrus coincided with a $15 \%$ increase in concentrations of pituitary FSH during the same period. Although these increases in basal release of FSH from explants and concentrations of pituitary FSH were significant statistically, the physiological importance of these quantitatively small increases remains to be determined. In the present study, these increases were not reflected in changes in the concentrations of serum FSH.

We conclude that, under these experimental conditions, numbers and affinity constants of GnRH-binding sites in the pituitary gland of post-partum beef cows do not limit the ability of the gland to release gonadotrophins.

We thank Dr John Gunther, Steve Lyth and Lisa Ritchey for technical assistance; Larry Chapin and James Liesman for computer programming; and Diana Baker for secretarial assistance. Michigan Agricultural Experiment Station Journal Article No. 11666. This work was supported in part by a grant from The Upjohn Company, Kalamazoo, Michigan, U.S.A. and by U.S.D.A. grant 82-CRSR-2-1044.

\section{References}

Carruthers, T.D., Convey, E.M., Kesner, J.S., Hafs, H.D. \& Cheng, K.W. (1980) The hypothalamo-pituitary gonadotrophic axis of suckled and nonsuckled dairy cows postpartum. J. Anim. Sci 51, 949-957.

Cermak, D.L., Braden, T., Manns, J., Niswender, G.D. \& Nett, T.M. (1983) Contents of hypothalamic GnRH, pituitary $\mathrm{FSH}$ and $\mathrm{LH}$, and pituitary receptors for GnRH and estradiol in postpartum beef cows. $J$. Anim. Sci, 57, Suppl. 1, 322, abstr. 462.

Clayton, R.N. \& Catt, K.J. (1981) Gonadotrophinreleasing hormone receptors: characterization, physiological regulation and relationship to reproductive function. Endocrine Reviews 2, 186-209.

Clayton, R.N., Shakespear, R.A., Duncan, J.A. \& Marshall, J.C. with appendix by Munson, P.J. \& Rodbard, D. (1979) Radioiodinated nondegradable gonadotropin-releasing hormone analogs: new probes for the investigation of pituitary gonadotropin-releasing hormone receptors. Endocrinology 105, 1369-1381.

Clayton, R.N., Solano, A.R., Garcia-Vela, A., Dufau, M.L. \& Catt, K.J. (1980) Regulation of pituitary receptors for gonadotropin-releasing hormone during the rat estrous cycle. Endocrinology 107, 699-706.

Convey, E.M., Beal, W.E., Seguin, B.E., Tannen, K.J. \& Lin, Y.C. (1976) Gonadotropin releasing hormone induced luteinizing hormone release after prostaglandin $\mathrm{F}_{2} \alpha$ in heifers. Proc. Soc. exp. Biol. Med. 151, 84-88.

Ferland, L., Marchett, B., Seguin, C., Lefebvre, F.A., Reeves, J.J. \& Labrie, F. (1981) Dissociated changes of pituitary luteinizing hormone-releasing hormone (LHRH) receptors and responsiveness to the neurohormone induced by $17 \beta$-estradiol and $\mathrm{LHRH}$ in vivo in the rat. Endocrinology 109, 87-93.

Fernandes, L.C., Thatcher, W.W., Wilcox, C.J. \& Call, E.P. (1978) $\mathrm{LH}$ release in response to $\mathrm{GnRH}$ during the postpartum period of dairy cows. J. Anim. Sci. 46, 443-448.

Gill, J.L. (1978) Design and Analysis of Experiments in the Animal and Medical Sciences, Vol. 1. Iowa State University Press, Ames.

Jenkin, G., Heap, R.B. \& Symons, D.B.A. (1977) Pituitary responsiveness to synthetic LH-RH and pituitary $\mathrm{LH}$ content at various reproductive stages in the sheep. J. Reprod. Fert. 49, $207-214$.

Jeppsson, S., Rannevik, G. \& Kullander, S. (1974) Studies on the decreased gonadotropin response after administration of $\mathrm{LH} / \mathrm{FSH}$-releasing hormone during pregnancy and the puerperium. Am. J. Obstet. Gynecol. 8, 1029-1034.

Kesler, D.J., Garverick, H.A., Youngquist, R.S., Elmore, R.G. \& Bierschwal, C.J. (1977) Effect of days postpartum and endogenous reproductive hormones on GnRH-induced LH release in dairy cows. J. Anim. Sci. 45, 797-803.

Labhsetwar, A.P., Collins, W.E., Tyler, W.J. \& Casida, L.E. (1964) Some pituitary-ovarian relationships in the periparturient cow. J. Reprod. Fert. 8, 85-90.

LeMaire, W.J., Shapiro, A.G., Riggall, F. \& Yang, N.S.T. (1974) Temporary pituitary insensitivity to stimulation by synthetic LRF during the postpartum period. J. clin. Endocr. Metab. 38, 916-918.

Leung, K., Padmanabhan, V., Convey, E.M., Short, R.E. \& Staigmiller, R.B. (1984) Relationship between pituitary responsiveness to Gn-RH and number of Gn-RH-binding sites in pituitary glands of beef cows. J. Reprod. Fert. 71, 267-277.

Lowry, O.H., Rosebrough, N.J., Farr, A.L. \& Randall, R.J. (1951) Protein measurement with the Folin phenol reagent. J. biol. Chem. 193, 265-275.

Millar, R.P., Rosen, H., Badminton, M., Pasqualini, C. \& Kerdelhue, B. (1983) Luteinizing hormone-releasing hormone (LH-RH) binding to purified rat pituitary nuclei. FEBS Letters 153, 382-386.

Morel, G., Barry, J. \& Dubois, P.M. (1980) Localisation ultrastructurale de la gonadoliberine $(\mathrm{GnRH})$ dans les cellules gonadotropes du Rat. Etude par immunocytochime apres cryo-ultra-microtomie. J. Physiol., Paris 76, 219-225. 
Moss, G.E., Adams, T.E., Niswender, G.D. \& Nett, T.M. (1980) Effects of parturition and suckling on concentrations of pituitary gonadotropins, hypothalamic $\mathrm{GnRH}$ and pituitary responsiveness to $\mathrm{GnRH}$ in ewes. J. Anim. Sci. 50, 496-502.

Naor, Z., Clayton, R.N. \& Catt, K.J. (1980) Characterization of gonadotropin-releasing hormone receptors in cultured rat pituitary cells. Endocrinology 107, 1144-1152.

National Research Council, Committee on Animal Nutrition (1976) Nutrient requirements of beef cattle. National Academy of Sciences, Washington, D.C.

Peters, A.R., Lamming, G.E. \& Fisher, M.W. (1981) A comparison of plasma LH concentrations in milked and suckled post-partum cows. J. Reprod. Fert. 62, 567-573.

Saiduddin, S., Riesen, J.W., Tyler, W.J. \& Casida, L.E. (1968) Relation of postpartum interval to pituitary gonadotrophins, ovarian follicular development and fertility in dairy cows. Res. Bull. Wisc. agric. Exp. Stn No. 270, pp. 1-54.
Savoy-Moore, R.T., Schwartz, N.B., Duncan, J.A. \& Marshall, J.C. (1980) Pituitary gonadotropinreleasing hormone receptors during the rat estrous cycle. Science, N.Y. 209, 942-944.

Sternberger, L.A. \& Petrali, J.P. (1975) Quantitative immunocytochemistry of pituitary receptors for luteinizing hormone-releasing hormone. Cell Tissue Res. 162, 144-176.

Webb, R., Lamming, G.E., Haynes, N.B., Hafs, H.D. \& Manns, J.G. (1977) Response of cyclic and postpartum suckled cows to injections of synthetic LH-RH. J. Reprod. Fert, 50, 203-210.

Williams, G.L., Kotwica, J., Slanger, W.D., Olson, D.K., Tilton, J.E. \& Johnson, L.J. (1982) Effect of suckling on pituitary responsiveness to gonadotropinreleasing hormone throughout the early postpartum period of beef cows. J. Anim. Sci. 54, 594-602.

Received 6 February 1985 